811.163.41'373.611

811.163.41367.622'37

811.163.41'373.42

https://doi.org/10.18485/sj.2018.23.1.7

РАЈНА М. ДРАГИЋЕВИЋ

Универзитет у Београду

Филолошки факултет
Оригинални научни рад

Примљен: 04. 01. 2018.

Прихваћен: 29. 01. 2018.

\title{
СЕМАНТИЧКА ДЕРИВАЦИЈА
}

У раду се говори о појму семантичка деривачија. Наводи се неколико схватања руских лингвиста, а затим и како су српски лингвисти, под утицајем руских, на различите начине усвајали овај појам и термин. Семантичка деривација спада у фундаменталне лексиколошке појмове и од његовог одређења зависи приступ и другим базичним појавама у лексичкој семантици, као што су полисемија, хомонимија, веза између полисемије и хомонимије, веза између полисемије и деривације итд. Ауторка овог рада подржава већину схватања јер се узајамно преплићу и не искључују се, а једно од њих изричито одбацује.

Кључне речи: семантичка деривација, полисемија, хомонимија, семантичка паралела, лексикологија, српски језик.

I. Увод. Повод за овај рад јесте једно мало неслагање између проф. Радмила Маројевића и ауторке овог текста. Разлог за неслагање заснован је на различитим теоријским концепцијама које подржавамо, а које се тичу појма семантичка дериваиија.

Кренућемо од примера који је подстакао неспоразум. У питању је тумачење односа између примарног и секундарног значења лексеме ручииа. У Речнику Матице српске, ручииа у свом примарном значењу представља $\mathbf{1 .}$ дем. и хип. од рука. - Дјечица се држе за ручице. Значење обележено као 2. а. гласи: део предмета (пољопривредног, ручног алата, посуђа, оружја и сл.)

"rajna.dragicevic@fil.bg.ac.rs 
који се држи или хвата руком, држак, дршка: ручица плуга, ручица ножа, погонска ручица.

Р. Маројевић сматра да су ручица-деминутив и ручица-предмет некада припадали истој полисемантичкој структури. Та структура се распала, па су данас ручица-деминутив и ручица-предмет две засебне лексеме у хомонимичном односу. Процес настајања хомонима цепањем некадашње полисемантичке структуре Р. Маројевић (2005: 685-686) назива семантичком деривацијом и убраја је у један од начина творбе речи.

Наше мишљење о овој интерпретацији изнели смо у раду Драгићевић (2008): „Ако су ручица као мала рука и ручица као део предмета у односу хомонимије, онда се поставља питање постоје ли уопште вишезначни деривати. Шта је са значењима 2.б. и 3 - да ли су и они хомоними? Ни у једном речнику неког словенског језика овај однос није представљен као хомонимијски. Било би необично очекивати да се четири очигледно повезана значења ручице представе у Речнику Матице српске као ручища ${ }^{1}$, ручица ${ }^{2}$, ручица ${ }^{3}$ и ручица ${ }^{4}$. И многи други деривати субјективне оцене су вишезначни (исп. нпр. главица: издвојено и заобљено брдо, брег у каквој равници; врх брда, брега, планине; испупчење, неравнина на земљи; капител, горњи, проширени део стуба; цваст лоптастог облика). Да ли се може рећи да ни њихова значења нису значења, већ посебне лексеме? Друго. Евентуално постојање ручице $e^{1}$ и ручице $e^{2}$ отвара и сложено питање критеријума хомонимичности. Како доказати да су ручица ${ }^{1}$ и ручий $a^{2}$ хомоними? Р. Маројевић то доказује лексемом печење, иако је случај ове лексеме сасвим другачији. Јасно је да су пѐчење и пече́ґе две лексеме, да је једна постала од друге, али различити акценти доказују да су у питању две лексеме. Оне чак нису ни прави хомоними, већ хомографи ${ }^{1}$. Ручица ${ }^{1}$ и ручица ${ }^{2}$ имају исти акценат, значењски су повезане лексеме, лако се може објаснити настанак ручице као дела предмета од ручице као мале руке. Па чак и да је ручииа као део предмета настала деривацијом од именице рука, а не полисемијом од деминутивног значења ручице, може ли се однос између две ручице прогласити хомонимијским? Питање односа полисемије и хомонимије једно је од најсложенијих питања у лексикологији (исп. Драгићевић 2010: 322-324). Чињеница је да распадом неких полисемантичких структура настају хомоними, али да ли је ручица пример за то?”

${ }^{1}$ Насупрот именици печење, која се заиста семантички раздвојила у две лексеме, неке друге глаголске именице задржале су значења у оквиру једне полисемантичке структуре. Такав је случај са именицом примање. У Речнику Матице српске она је забележена у четири значења: 1. гл. им од примати (се). 2. дочек, пријем. 3. скуп или састанак позваних особа (обично званичних) у знак почасти кога или чега, пријем. 4. а. оно ито се прима као зарада или накнада за нешто. б. дневни оброк хране или нешто друго што коме припада по прописима. Ова значења су очигледно повезана и представљају једну полисемантичку структуру. 
Мишљење проф. Р. Маројевића није, међутим, усамљено и базира се на једном од тумачења појма (и термина) семантичка дериваиија. Овај рад посветићемо том појму јер се показује да се његовим осветљавањем фокусирају нека од фундаменталних питања лексичке семантике.

II.1. СемантичКА ДЕРИвацИјА КАО ГеНЕРАТОР хомОНИМИјЕ. Теоријско Полазиште проф. Маројевића утемељено је на схватањима значајних руских лингвиста Л. В. Шчербе, А. А. Потебње и, у потпуности, на размишљањима В. В. Виноградова. Л. В. Шчерба (2009: 16) 1940. године објавио је рад који се сматра првим текстом посвећеним теоријској лексикографији, где је написао да је „неправилно мислити да речи имају више значења: то је формална и чак типографска тачка гледишта. У ствари, има онолико речи колико дата реч има значења (тако су се и штампали стари речници: одредница се понављала онолико пута колико има значења)." Исто мишљење имао је и А. А. Потебња (1958: 15-16), који је сматрао да не постоји вишезначност, већ само истозвучност различитих речи. В. В. Виноградов (1977) писао је о лексичко-семантичком типу творбе речи који се изводи тако што се распадом једне полисемантичке структуре формирају хомоними, као две нове лексеме. Баш на овај начин семантичкој деривацији приступа и проф. Р. Маројевић.

II.2. СЕМАНТИЧКА ДЕРИВАЦИЈА КАО ГЕНЕРАТОР ПОЛИСЕМИЈЕ. Ј. Д. АПресјан (1995: 188-189), међутим, третира семантичку деривацију као генератор полисемије и запажа да је у науци дошло до ревидирања односа према хомонимији (нпр. у радовима О. С. Ахманове), што је утицало на промену приступа према полисемији, деривацији, као и семантичкој деривацији. Новонастале промене у другој половини XX века Ј. Д. Апресјан повезује у два основна приступа. Према првом, полисемија је блиска деривацији и семантички и формално, а према другом, полисемија је блиска деривацији у семантичком смислу, али не и формално.

У истраживаче који полисемију повезују са деривацијом и семантички и формално, Апресјан убраја Џ. Лајонса и, као пример, наводи његово тумачење енглеских глагола close, move, split итд. Сви ови глаголи данас имају и каузативно и некаузативно значење, док су у прошлости, према Лајонсу, некаузативни глаголи имали своје каузативне парњаке у лексикализованом виду. Тако, на пример, наспрам die (умрети) постоји kill (убити), наспрам see (видети) постоји show (показати) итд. Џ. Лајонс сматра да могућност глагола да развијају каузативна значења представља семантичку промену, али и морфолошку (,посредством морфолошког процеса нулте модификације”).

Према Апресјану (1995: 189), Д. Н. Шмељов спада у лингвисте који уочавају семантичку везу између полисемије и деривације, и то у метонимијским преносима. Говорећи о регуларности метонимије, тј. о чињеници да сви чланови једне тематске групе лексема подлежу истом метонимијском моделу 
(нпр. Цео град/село/варош/крај спава), он запажа да је та регуларност карактеристична за деривацију, па овакав процес назива семантичком дериваиијом. Слично је размишљао и В. Г. Гак, који је запазио да у француском језику често долази до семантичких промена лексема које нису праћене морфолошким, па ову појаву назива семантичком конверзијом.

У српској лингвистици на овај начин семантичкој деривацији приступа J. Матијашевић (1987), која сматра да се као резултат семантичке деривације добија ново значење лексеме, а не нова лексема.

Дакле, на крају овог одељка закључујемо да су неки лингвисти посматрали семантичку деривацију као семантички процес унутар једне лексеме који доводи до настајања а) нове лексеме/хомонима (исп. В. В. Виноградов, Р. Маројевић) или б) новог значења у оквиру једне полисемантичке структуре (исп. Ј. Д. Апресјан, Ј. Матијашевић).

III. СЕМАНТИЧКА ДЕРИВАЦИЈА КАО ВЕЗА ПОЛИСЕМИЈЕ И ДЕРИВАЦИЈЕ. ИсПИТУјУћИ семантичку деривацију као генератор полисемије, примећено је да је тај однос сложен и да о њему можемо говорити бар на два начина. С једне стране, као резултат семантичке деривације настају нова значења (тј. полисемија је резултат семантичке деривације) и, с друге стране, полисемија и деривација су сродни процеси који су засновани на сличним принципима и дају сличне резултате.

Ј. Д. Апресјан (1995: 189) уочава аналогију између деривације и полисемије која се огледа у сличним појавама које карактеришу оба процеса, а то су регуларност - нерегуларност, продуктивност - непродуктивност итд. J. Д. Апресјан показује на бројним примерима продуктивне и непродуктивне типове регуларне полисемије, која се постиже углавном метонимијом, а у ретким случајевима и метафором.

У српској лингвистици је на сличан начин размишљала Д. Гортан Премк (2004: 136-139). Она употребљава заједнички термин за полисемију и деривацију, а то је семантичко варирање. Употребом заједничког термина (термина хиперонима) за ове две појаве Д. Гортан Премк наглашава сличност у њиховом функционисању. „Полисемија (семантичка деривација) је семантичко варирање у оквиру једне лексеме [...] Деривација (семантичко-морфолошка деривација) је семантичко варирање између двеју лексема" (Гортан Премк 2004: 137). Д. Гортан Премк наводи као пример чињеницу да, као што глава може да се односи на главу човека и главу животиње, тако, у даљем варирању, дериват главоњ $а$ (онај који има велику главу) може да се односи и на човека и на животињу (глава дечака и глава мачора: главоња дечак и главоња мачак). Према Д. Гортан Премк (2004: 138-139), ,,регуларност је семантичког варирања истовремено - несумњива и вероватна. Несумњива је што се семасиолошких процеса тиче; они су исти и у полисемији и у деривацији. Ови се процеси у оба типа варирања заснивају на платисемији, метонимији, синегдохи и мета- 
фори. Несумњаива је регуларност и што се резултата ових процеса тиче; и у једноме и у другоме варирању резултат је нова лексичка јединица, у полисемији - ново значење исте лексеме, у деривацији - нова лексема добијена од старе, полазне, и каквог творбеног форманта. Вероватна је што се тиче могућности прогнозе циљне, секундарне лексичке јединице, оне која се добија као резултат семантичког варирања.”

IV. СЕМАНТИЧКА ДЕРИВАЦИЈА КАО ВЕЗА СИНХРОНИЈСКИХ И ДИЈАХРОНИЈСКИХ СЕМАНТичкИХ ПРОцЕСА. Према А. Зализњак (2001: 16), идеја о томе да се синхронијски однос међу различитим значењима вишезначне речи и однос између изворног и добијеног значења у дијахронијској перспективи представљају две стране исте појаве. Ово су запазили и О. Н. Трубачов, В. В. Виноградов, Н. И. Толстој и многи други. Један од важних појмова у вези с овом појавом јесте појам семантичка паралела, а то је факт аналошког семантичког развоја лексеме с тим истим значењем у другом језику. Термин се користи у етимологији, често као аргумент у корист претпостављене семантичке везе међу језичким јединицама. А. Зализњак наводи пример руског придева наглый, који Трубачов изводи из словенског корена $n a g$ - (го), имајући у виду дијалекатско значење чист, прави, и то поткрепљује чињеницом да у немачком језику bar (го) и чист, прави (bargeld) имају исти корен.

У наставку свог рада, А. Зализњак предлаже Каталог семантичких деривација, чији би циљ био да опише регуларне семантичке измене за потребе даљих типолошких истраживања. Циљ је инвентаризација, а не класификација, наглашава А. Зализњак. Она констатује да идеја о таквом каталогу није нова и да је још 1964. године О. Н. Трубачов предлагао Словарь семантических переходов. Кључно теоријско питање у вези са оваквим подухватом јесте скала измене, која у различитим примерима може бити мања или већа. Зато je А. Зализњак поставила неке критеријуме: различитим значењима сматраће се она за које постоје синоними у виду једне речи; најудаљенија значења су у односу хомонимије.

Јединица каталога јесте семантичка деривачија. Она се схвата као двострана појава, тј. јединица која има план садржаја и план израза. Прво се наводи лексички пар који је повезан односом семантичке деривације (a $\leftrightarrow$ b), а затим реализације датог семантичке трансформације, тј. списак речи у којима је он реализован (синхронијски и дијахронијски). Као пример навешћемо обраду једне јединице, тј. једне семантичке деривације из Каталога, а то је семантичка деривација плохой (лош) ↔ злой (пакостан, љут) (исп. Зализњак 2001: 17).

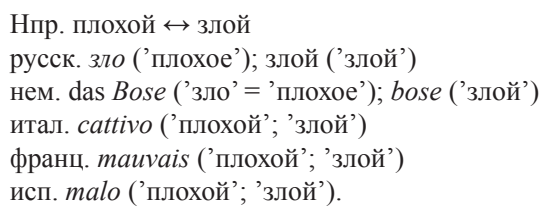


Ако није у потпуности јасан смер семантичке деривације, тј. податак о томе које је значење старије, онда се, као у наведеном примеру, приказује двосмерна стрелица, а ако је процес јасан, онда се стрелицом указује на чињеницу које је значење изворно, а које је настало као резултат семантичке деривације. Међутим, утврђивање смера стрелице представља велики проблем. Ево примера (А. Зализњак 2001: 18), 'быстро передвигаться' (брзо се кретати) $\leftrightarrow$ 'течь' (тећи):

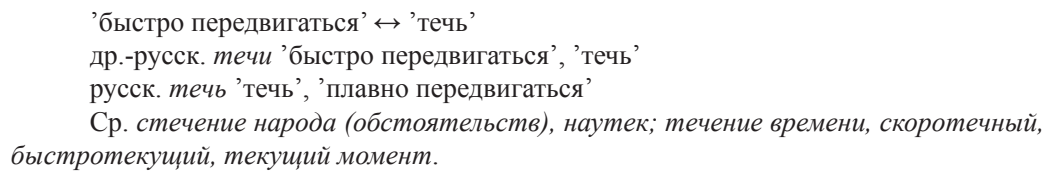

А. Зализњак коментарише да је из угла савременог језика у овом примеру дошло до метафоричке употребе глагола тећи и да је процес ишао у овом смеру: $\mathrm{a} \leftarrow \mathrm{b}$, а историјски (тј. реално) процес је ишао у обрнутом смеру $\mathrm{a} \rightarrow \mathrm{b}$, дошло је до спецификације (сужавања) значења. А. Зализњак наводи и бројне друге проблеме, који се могу претпоставити у изради једног оваквог каталога, а посебну пажњу посвећује проблему семантичког калкирања, које може да поквари слику реалних, регуларних семантичких деривација, које су настајале као резултат покретања унутрашњих језичких механизама.

Приступ семантичкој деривацији Ане Зализњак, који се заснива на уочавању блискости синхронијских и дијахронијских творбено-семантичких процеса, као и семантичких процеса у различитим језицима заступа и Зузана Тополињска и у неколико својих радова последњих година истражује семантичку деривацију на различитим примерима у више словенских језика. „Процес семантичке деривације”, каже 3. Тополињска (у штампи), „разумем као трансфер значења једне лексеме на другу, што се на површини испољава као формална деривација, тј. као рађање нове лексеме која представља дериват лексеме-даваоца. Значи, формално гледано, процес се одвија у оквиру деривационог гнезда, а његова је функција ширење одређених семантичких компоненти у датом гнезду." У неким радовима, 3. Тополињска анализира творбено-семантичке процесе у основи семантичке деривације, а у неким истраживањима фокус ставља на резултате семантичких процеса до којих је дошло под утицајем одређених процеса.

V. РАЗМАТРАњЕ ИЗЛОЖЕНИХ ПРИСТУПА И ЗАКљУЧАК. Кроз овај НајКраћи ПрегЛед приступа семантичкој деривацији, кроз различите дефиниције и критеријуме за њено разумевање, изложили смо и нека од фундаменталних питања лексикологије.

Прво смо изложили она схватања која семантичку деривацију дефинишу као процес унутар једне лексеме. Захваљујући активности неких семантичких компонената, унутар лексеме настаје нови лексички резултат - неки аутори тај 
резултат тумаче као ново значење (резултат полисемије), а други га схватају као нову лексему (хомоним). Ова два погледа нису тек две нијансе истог виђења семантичке деривације, већ су у питању два приступа полисемији и хомонимији и граници међу њима. Сматрамо да се хомонимији не може приступати као појави која настаје системски, активношћу семантичких компонената лексеме. Ако постоји значењска веза између два семантичка садржаја, не може се говорити о хомонимији. У потпуности прихватамо оцену Д. Гортан Премк (2004: 150) да хомонимија није системска појава, да је она само факат у лексичком систему и да представља „само могућност постојања двају или више диверзних семантичких садржаја у формално, по спољашњем изгледу, истоме облику.” Ако бисмо прихватили идеју да ручица (мала рука) и ручица (предмет) спадају у хомониме, онда бисмо практично укинули полисемију, која је један од најважнијих покретача свих процеса у лексичком систему. Ипак, сматрамо корисним и важним стално преиспитивање и разматрање границе између полисемије и хомонимије, јер не треба сметнути с ума ни чињеницу да у неким случајевима хомонимија заиста настаје распадом некадашњих полисемантичких структура, али о тој појави можемо говорити само у оним ретким случајевима када између два семантичка садржаја нема никакве семантичке повезаности из угла савременог језика. ${ }^{2}$

Изложили смо и она схватања семантичке деривације која подразумевају уочавање паралела у семантичком понашању између две лексеме. Изнели смо размишљање да проста реч и њен дериват развијају полисемантичку структуру по истом моделу, као и став да синхронијски однос међу различитим значењима вишезначне речи и однос између изворног и добијеног значења у дијахронијској перспективи представљају два лица исте појаве. И овакви приступи семантичкој деривацији драгоцени су јер у први план износе важне појаве које одржавају лексику једног језика као систем, а то су законитости регуларности, аналогије, продуктивности итд. Износећи неке поставке о семантичкој деривацији, имали смо прилику да нагласимо значај, на пример, регуларности за успостављање везе између полисемије и деривације, између синхронијских и дијахронијских семантичких процеса, као и између семантичких процеса у лексичким системима различитих језика.

Наша намера није да се опредељујемо за један одређени приступ семантичкој деривацији, већ да укажемо на необично важне закључке о организацији лексичког система који произлазе из различитих приступа семантичкој деривацији.

${ }^{2}$ Тако су, на пример, лексеме конай (нит, жица, влакно), конай (заврини, последьи тренутак неког временског периода) и коначз (глежағ, чланак) повезани истим индоевропским кореном *ken- са општим значењем потицања, порекла и настале су распадом некадашње полисемантичке структуре, али из угла савременог српског језика међу њима не постоји никаква семантичка веза (исп. Гортан Премк 2004: 152). 


\section{ЛИТЕРАТУРА}

Апресјан 1995: Ю. Д. Апресян, Лексическая семантика. Синонимичекие средства языка. Изабранные труды, том I, Москва: Языки русской культуры. Восточная литература. РАН.

Виноградов 1977: В. В. Виноградов: „Основные типы лексических значений слова”, Избранные труды. Лексикология и лексикография, Москва: Наука, 162-189.

Гортан Премк 2004: Даринка Гортан Премк, Полисемија и организаиија лексичког система у српскоме језику, Београд: Завод за уџбенике и наставна средства.

Драгићевић 2008: Рајна Драгићевић: „Творбени и семантички статус једног значења именица типа ручииа, Српски језик XIII/1-2, 203-215.

Драгићевић 2010: Рајна Драгићевић, Лексикологија српског језика, друго издање, Београд: Завод за уџбенике и наставна средства.

Зализњак 2001: А. А. Зализняк: „Семантическая деривация в синхронии и диахронии", проект Каталога семантических переходов, Bonросы языкознания № 2, 13-25.

Маројевић 2005: Радмило Маројевић: „Творба речи у савременом српском језику Ивана Клајна (1)”, Српски језик 10/1-2, 685-780.

Матијашевић 1987: Јелка Матијашевић: „Око неких питања у творби речи”, Научни састанак слависта у Вукове дане, књ. 16/1, 109-119.

Потебња 1958: А. А. Потебня, Из записок по русской грамматике, I-II, Москва: Учпедгиз.

Тополињска (у штампи): Зузана Тополињска: „Полски-македонски: термална обработка на храна", Језик као запис културе у етнолошкој и лингвистичкој анализи на релачија Србија-Македонија, главни и одговорни уредници П. Пипер и М. Марковић, Београд: САНУ.

Тратникова 2015: А. В. Тратникова: „Понятие семантической деривации”, Актуальные вопросы филологических наук: материалы III Междунар. Науч. Конф. (г. Казань, октябрь 2015 г.), Казань: Бук.

Шчерба 2009: Л. В. Щерба: „Опыт общей теории лексикографии”, Лексикография русского языка, сосатавители: Л. А. Ивашко, И. С. Лутовинова, Д. М. Поцепня, М. А. Тарасова, Санкт-Петербург: Факультет филологии и искусств Санкт-Петербургского государственного университета, 5-25 (рад је прештампан из неколико ранијих издања). 


\section{ИЗВОР:}

Речник Матице српске: Речник српскохрватскога књижевног језика, I-VI, Нови Сад: Матица српска, 1967-1976.

\section{SEMANTIC DERIVATION}

\section{Summary}

This paper deals with the concept of semantic derivation. A several views of Russian linguists is presented, and then it is discussed how the Serbian linguists, under the influence of the Russians, adopted in different ways this term. This concept belongs to fundamental lexicological concepts and based on its determination the understanding of other basic phenomena in lexical semantics are explained, such as polysemy, homonymy and their connection, and the connection between polysemy and derivation, and so on. The author supports most of the concepts because they interweave and complement each other, but one explicitly rejects.

Key words: semantic derivation, polysemy, homonymy, semantic parallel, lexicology, Serbian language.

Rajna M. Dragićević 